\section{A 10-year ecological study of the methods of suicide used by Brazilian adolescents}

\section{Estudo ecológico de 10 anos sobre os métodos de suicídio usados por adolescentes brasileiros}

\section{Estudio ecológico abarcando 10 años sobre los métodos de suicidio practicados por adolescentes brasileños}

\author{
Denisse Claudia Jaen-Varas 1 \\ Jair J. Mari 1,2 \\ Elson Asevedo 1,3 \\ Rohan Borschmann 4,5 \\ Elton Diniz 1 \\ Carolina Ziebold 1,2 \\ Ary Gadelha 1,2
}

doi: 10.1590/0102-311X00104619

\begin{abstract}
Suicide among adolescents has become a major public health problem worldwide. Our study sought to describe the most commonly used methods of suicide among adolescents aged 10 to 19 years in Brazil between 2006 and 2015. Complete data were obtained from the Brazilian Health Informatics Department (DATASUS) and coded into seven categories of suicide methods. The following statistical analyzes were performed: chi-square $\left(\chi^{2}\right)$ tests to examine the association between the frequency of each suicide method and the year; odds ratios $(\mathrm{OR})$ and 95\% confidence intervals (95\%CI) compared the relative chances of each suicide method occurring between boys and girls. In total, 8,026 suicides among Brazilian adolescents were registered over the analyzed

\author{
Correspondence \\ D. C. Jaen-Varas \\ Universidade Federal de São Paulo. \\ Rua Major Maragliano 241, São Paulo, SP 04017-030, Brasil. \\ deni_clau@hotmail.com \\ 1 Universidade Federal de São Paulo, São Paulo, Brasil. \\ 2 Instituto Nacional de Psiquiatria do Desenvolvimento para \\ Crianças e Adolescentes, São Paulo, Brasil. \\ 3 Global Mental Health Program, Columbia University, New \\ York, U.S.A. \\ ${ }_{4}$ Melbourne School of Psychological Sciences; University of \\ Melbourne, Melbourne, Australia. \\ 5 Centre for Adolescent Health, Murdoch Children's Research \\ Institute, Melbourne, Australia.
} period. The most commonly used method of suicide by both sexes was hanging $(2015=70.3 \%)$, and the most significant increase was observed in girls $(2015=65.82 \%)$. The proportional use of arms $(2006=14.2 \% ; 2015=9.1 \%)$ and poisoning $(2006=13.3 \% ; 2015=9.2 \%)$ decreased over the period. The increase in hanging is worrisome, mostly due to difficulties to impose access barriers and to its high lethality. In such context, a comprehensive understanding of suicide behaviors among adolescents in Brazil should be drawn to inform general prevention measures and, more specifically, the reasons for the increase in hanging need to be further investigated.

Adolescent; Mental Health; Suicide; Prevention; Time Series Studies 


\section{Introduction}

Globally, more than 800,000 deaths from suicide are recorded every year and it is the second leading cause of death among people 15-29 years old, thus becoming a major public health concern worldwide 1. An analysis of the World Health Organization (WHO) showed minor changes in the average suicide rate of children aged 10-14 years 2 . On the other hand, suicide rates among adolescents aged 15-19 years significantly increased in South America (boys: from 7.36 to 11.47 per 100,000; girls: from 5.59 to 7.98 per 100,000) 3 .

In Brazil, the WHO also indicated an increase in suicide rates among adolescents aged 15-19 years from 1990-2009 3. Additionally, a study showed an increase in the age-adjusted suicide rate among adolescents of 9\% between 2006 and 2015 4. Moreover, another study showed that the suicide rate of adolescents increased by 24\% in six large Brazilian cities and by 13\% in the country between 2006 and 2015 .

One study about suicide methods in adolescents aged 10-19 years from the WHO Mortality Database (2000-2009), with 86,280 suicide cases recorded in 101 countries, showed that the most frequent suicide method for both gender and age groups was hanging; additionally, boys used almost twice more hanging or firearms than girls, who chose slightly more poisoning (by pesticides or drugs) and jumping from heights 6 .

A few studies about suicide methods among adolescents have been conducted in Brazil. They have used data from the Health Informatics Department (DATASUS) that covered three decades; however, these studies have used information collected before 2007. One study analyzed suicide among young Brazilians between 15 and 24 years in nine Metropolitan Regions, from 1979 to 1998, concluding that the main suicide methods used were hanging, strangulation and suffocation, mainly in Porto Alegre, and the use of arms and explosives, in Belo Horizonte 7.

Another study in Brazil examined the methods of suicide between 1980 and 2006. In most regions and in different age groups, the most frequent methods of suicide among adolescents aged 10-19 years were hanging, arms and poisoning 8 . Regional differences of suicide methods were observed: in the Northeast region, hanging (48.8\%), poisoning (18.2\%) and arms (16.9\%) were the predominant suicide methods; in the Southeast, hanging (39.6\%), other methods (24.2\%) and arms (16.5\%) prevailed 8.

In another study carried out in Minas Gerais State, Brazil, between 1996 and 2002, the main method of suicide among adolescent boys was hanging/strangulation/suffocation (1.1 per 100,000 inhabitants), followed by use of arms (0.6 deaths per 100,000 inhabitants). Among women, the methods were hanging/strangulation/suffocation and self-intoxication with poisoning and pesticide ( 0.3 deaths per 100,000 inhabitants) 9 .

In Brazil, governmental efforts for suicide prevention have been relatively modest. More consistent strategies started in the last two decades, as indicated by the launching of the National Strategy for Suicide Prevention in 2006 10. Increasing mental health assistance coverage was the most implemented strategy. Moreover, psychosocial care services have a fundamental role in the prevention of suicide, especially where there are Centers for Psychosocial Care (CAPS), an initiative of the Brazilian Unified National Health System (SUS) 11.

The aims of this study are (i) to describe the methods of suicide most commonly used by adolescents aged 10-19 years in Brazil between 2006 and 2015, and (ii) examine if these methods differ by gender. This information could inform prevention strategies and public health policies, limiting access to these methods.

\section{Methods}

This study has 10-year ecological design, from January 2006 to December 2015. Data on the suicide methods used by adolescents in Brazil were collected according to the chronological limits of adolescence (10-19 years) and gender.

We obtained records on suicide methods for 10 years from the DATASUS (http://tabnet. datasus.gov.br/cgi/deftohtm.exe?sim/cnv/obt10br.def, accessed on 21/Mar/2018), since the data were complete 12 . 
In Brazil, suicide methods are registered using the 10th revision of the International Classification of Diseases (ICD-10) 13: intentional self-harm (X60-X84), event of undetermined intent (Y10-Y19), and sequelae of intentional self-harm and events of undetermined intent (Y87.0). The last two categories were included in the analyses according to recommendations of the Brazilian Ministry of Health, due to possible failures in the codification of the cause of suicide in these groups 14. Data on suicide methods in Brazil derive from information contained in death certificates compiled by the Mortality Information System (SIM) of the Ministry of Health 14. In our study, suicide methods were categorized into seven groups: hanging/drowning (ICD-10 codes X70 and X71), self-intoxication (codes $\mathrm{X} 60-\mathrm{X} 67, \mathrm{X} 69$, Y11-Y17, and Y19), poisoning by pesticides (codes X68 and Y18), use of arms (codes $\mathrm{X} 72$-X79), jumping from heights (code X80), jumping/laying in front of a moving object/crashing of motor vehicles (codes X81 and X82), and "other methods" include intentional self-harm by other specified means (caustic substances, except poisoning; crashing of aircraft and electrocution), and intentional self-harm by unspecified means (codes X83 and X84) ${ }^{13}$. All information was complete on the DATASUS database.

\section{Ethics aspects}

This study was approved by the Ethics Research Committee of the Federal University of São Paulo (CEP-UNIFESP) and the São Paulo Hospital of Brazilian Platform with protocol n. 3,006,523.

\section{Statistical analysis}

The data were obtained from the DATASUS and coded into the seven aforementioned categories of suicide methods, disaggregated by gender. Statistical analyses were performed using the MedCalc Software, version 18.11 (https://www.medcalc.org/). Descriptive statistics were reported in terms of frequency and proportion of each suicide method by year and gender. Chi-squared tests $\left(\chi^{2}\right)$ with a 0.05 significance level were performed to compare the frequency of each suicide method in 2006 and 2015. Odds ratios (OR) and 95\% confidence intervals (95\%CI), and z-tests with corresponding p-values (also with a 0.05 significance level) were estimated to compare the relative odds of the occurrence of each method of suicide among boys (category of reference) and girls.

\section{Results}

In total, 8,026 cases of suicide among Brazilian adolescents aged between 10-19 years were registered during the study period. In 2006 (Table 1), 804 cases of suicide in this age group were registered, 529 boys (65.8\%) and 275 girls (34.2\%). Hanging was the most frequent method (54.9\%), followed by the use of arms (14.2\%), self-intoxication (13.3\%) and pesticides (10.7\%); the less frequently used methods were jumping from height (2.9\%), other methods (2.7\%) and jumping/laying in front of moving objects/crashing of motor vehicles (1.1\%). In 2015 (Table 2), 892 cases of suicide were registered, with 617 boys (69.2\%) and 275 girls (30.8\%), showing a significant increase when compared with 2006 in hanging $\left(70.3 \%,+15.4 \%, \chi^{2}(1)=43.00, \mathrm{p}<0.001\right)$ and a non-significant increase in jumping from height $\left(4.3 \%,+1.4 \%, \chi^{2}(1)=2.36, \mathrm{p}=0.12\right)$; there were significant reductions in the use of arms $(9.1 \%$, $\left.-5.1 \%, \chi^{2}(1)=10.79, \mathrm{p}=0.001\right)$, self-intoxication $\left(9.2 \%,-4.1 \%, \chi^{2}(1)=7.17, \mathrm{p}=0.007\right)$, pesticides $(4.9 \%$, $\left.-5.8 \%, \chi^{2}(1)=20.12, \mathrm{p}<0.001\right)$ and other methods $\left(1.2 \%,-1.5 \%, \chi^{2}(1)=5.07, \mathrm{p}=0.02\right)$. Jumping/laying in front of moving objects/crashing of motor vehicles remained relatively low and constant between 2006 and $2015\left(1.0 \%,-0.1 \%, \chi^{2}(1)=0.04, p=0.84\right)$. Figure 1 shows the variations in the methods of suicide used by Brazilian adolescents between 2006 and 2015. Hanging has increased, becoming the method most used by adolescents. The other methods have remained the same.

Comparisons by sex showed that in 2006 , boys more frequently used hanging $(\mathrm{OR}=2.63,95 \% \mathrm{CI}$ : $1.95-3.54)$ and arms ( $\mathrm{OR}=2.02$, 95\% CI: 1.26-3.24) than girls, whereas boys less frequently used pesticides (OR $=0.24,95 \% \mathrm{CI}$ : 0.15-0.38), self-intoxication (OR $=0.37$, 95\%CI: $0.24-0.55)$ and other methods (OR $=0.42$, 95\%CI: 0.18-0.99) than girls. In 2015, boys used arms significantly more frequently $(\mathrm{OR}=2.08,95 \% \mathrm{CI}: 1.16-3.71)$ than girls, whereas boys used less self-intoxication $(\mathrm{OR}=0.43,95 \% \mathrm{CI}$ : 
Table 1

Suicide methods for boys and girls aged 10-19 years in Brazil in 2006.

\begin{tabular}{lccccccccc}
\hline Suicide methods & \multicolumn{2}{c}{ Total } & \multicolumn{2}{c}{ Boys } & \multicolumn{2}{c}{ Girls } & \multicolumn{3}{c}{ Boys vs. girls } \\
& $\mathbf{n}$ & $\mathbf{\%}$ & $\mathbf{n}$ & $\mathbf{\%}$ & $\mathbf{n}$ & $\mathbf{\%}$ & OR & $\mathbf{9 5 \% C l}$ & SE \\
\hline Hanging/Drowning & 441 & 54.9 & 333 & 75.5 & 108 & 24.5 & $\mathbf{2 . 6 3}$ & $\mathbf{1 . 9 5 - 3 . 5 4}$ & 0.15 \\
Self-intoxication & 109 & 13.3 & 49 & 45.0 & 60 & 55.0 & $\mathbf{0 . 3 7}$ & $\mathbf{0 . 2 4 - 0 . 5 5}$ & 0.21 \\
Pesticide & 86 & 10.7 & 30 & 34.9 & 56 & 65.1 & $\mathbf{0 . 2 4}$ & $\mathbf{0 . 1 5 - 0 . 3 8}$ & 0.24 \\
Arms & 114 & 14.2 & 89 & 78.1 & 25 & 21.9 & $\mathbf{2 . 0 2}$ & $\mathbf{1 . 2 6 - 3 . 2 4}$ & 0.24 \\
Jumping from heights & 23 & 2.9 & 12 & 52.2 & 11 & 47.8 & 0.56 & $0.24-1.28$ & 0.43 \\
Moving objects/Crashing & 9 & 1.1 & 6 & 66.7 & 3 & 33.3 & 1.04 & $0.26-4.19$ & 0.71 \\
Other & 22 & 2.7 & 10 & 45.5 & 12 & 54.5 & $\mathbf{0 . 4 2}$ & $\mathbf{0 . 1 8 - 0 . 9 9}$ & 0.43 \\
Total & 804 & 100.0 & 529 & 65.8 & 275 & 34.2 & & & \\
\hline
\end{tabular}

95\%Cl: 95\% confidence interval; OR: odds ratio; SE: standard error.

Note: significant values $(p<0.05)$ in bold.

\section{Table 2}

Suicide methods used by boys and girls aged 10-19 years in Brazil in 2015.

\begin{tabular}{lccccccccc}
\hline Suicide methods & \multicolumn{2}{c}{ Total } & \multicolumn{2}{c}{ Boys } & \multicolumn{3}{c}{ Girls } & \multicolumn{3}{c}{ Boys vs. girls } \\
& $\mathbf{n}$ & $\mathbf{\%}$ & $\mathbf{n}$ & $\mathbf{\%}$ & $\mathbf{n}$ & $\mathbf{\%}$ & OR & $\mathbf{9 5 \% \mathbf { C l }}$ & SE \\
\hline Hanging/Drowning & 627 & 70.3 & 446 & 71.1 & 181 & 28.9 & 1.35 & $0.99-1.84$ & 0.16 \\
Self-intoxication & 82 & 9.2 & 42 & 51.2 & 40 & 48.8 & $\mathbf{0 . 4 3}$ & $\mathbf{0 . 2 7 - 0 . 6 8}$ & 0.24 \\
Pesticide & 44 & 4.9 & 25 & 56.8 & 19 & 43.2 & 0.57 & $0.31-1.05$ & 0.31 \\
Arms & 81 & 9.1 & 66 & 81.5 & 15 & 18.5 & $\mathbf{2 . 0 8}$ & $\mathbf{1 . 1 6 - 3 . 7 1}$ & 0.30 \\
Jumping from heights & 38 & 4.3 & 26 & 68.4 & 12 & 31.6 & 0.96 & $0.48-1.94$ & 0.36 \\
Moving objects/Crashing & 9 & 1.0 & 5 & 55.6 & 4 & 44.4 & 0.55 & $0.15-2.08$ & 0.67 \\
Other & 11 & 1.2 & 7 & 63.6 & 4 & 36.4 & 0.78 & $0.23-2.68$ & 0.63 \\
Total & 892 & 100.0 & 617 & 69.2 & 275 & 30.8 & & & \\
\hline
\end{tabular}

95\%Cl: 95\% confidence interval; OR: odds ratio; SE: standard error.

Note: significant values $(p<0.05)$ in bold.

\section{Figure 1}

Changes in the methods of suicide used by Brazilian adolescents between 2006 and 2015.

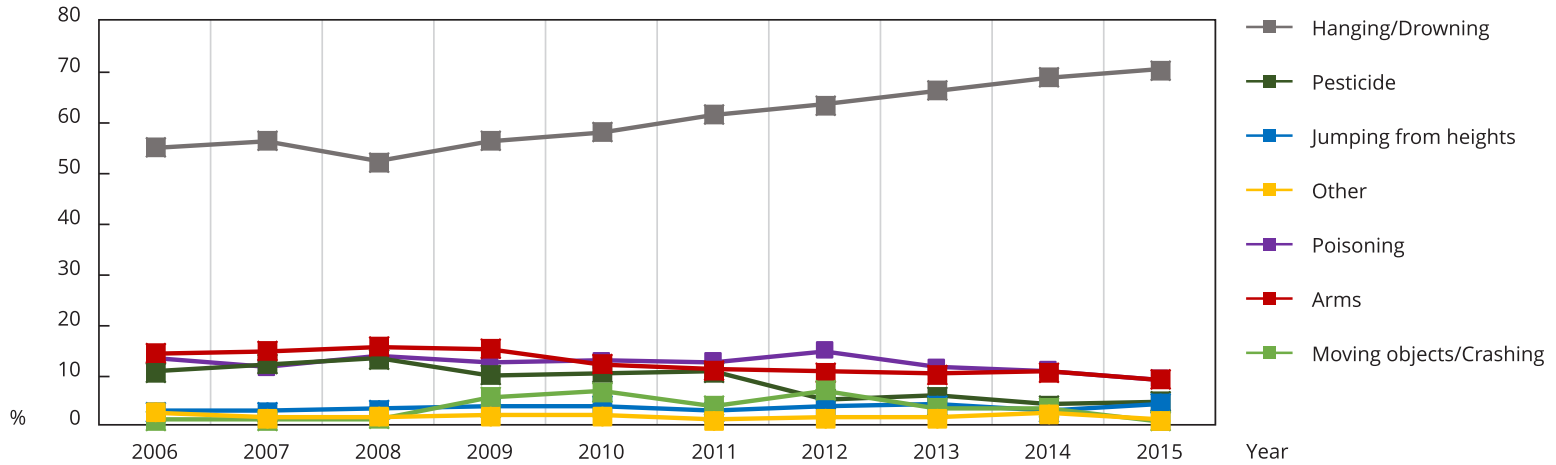


0.27-0.68) than girls (Table 1). According to Figure 2, hanging increased in both sexes from 2006 to 2015 (boys: $+9.4 \%, \chi^{2}(1)=12.1, \mathrm{p}=0.0005$; girls: $\left.+26.7 \%, \chi^{2}(1)=38.94, \mathrm{p}<0.001\right)$. Between 2006 and 2015 , suicide by arms decreased significantly only among boys $\left(-5.9 \%, \chi^{2}(1)=8.51, \mathrm{p}=0.004\right)$. Suicide by self-intoxication decreased in both sexes (boys: $-3.59 \%, \chi^{2}(1)=5.39, \mathrm{p}=0.02$; girls: $-7.27 \%, \chi^{2}(1)=$ 4.88, $\mathrm{p}=0.03$ ), whereas the use of pesticides showed a significant decrease from 2006 to 2015 only among girls $\left(-13.45 \%, \chi^{2}(1)=21.09, \mathrm{p}<0.001\right)$.

\section{Discussion}

The use of suicide methods by boys and girls varied between January 1, 2006, and December 31, 2015, with hanging increasing by $15 \%$. In the same period, the use of arms and self-intoxication by poisoning and pesticide reduced. The understanding of the possible factors underlying such changes could help to define future interventions.

The total proportion of suicides in adolescents by the use of arms between 200 and 2015 decreased from $14.2 \%$ to $9.1 \%$ possibly due to the Disarmament Statute (Law n. 10,826/2003) 15, which updated the legislation on registration, possession and trade of arms in Brazil, restricting the access to arms.

Figure 2

Changes in the methods of suicide used by Brazilian adolescents between 2006 and 2015 .

2a) Girls

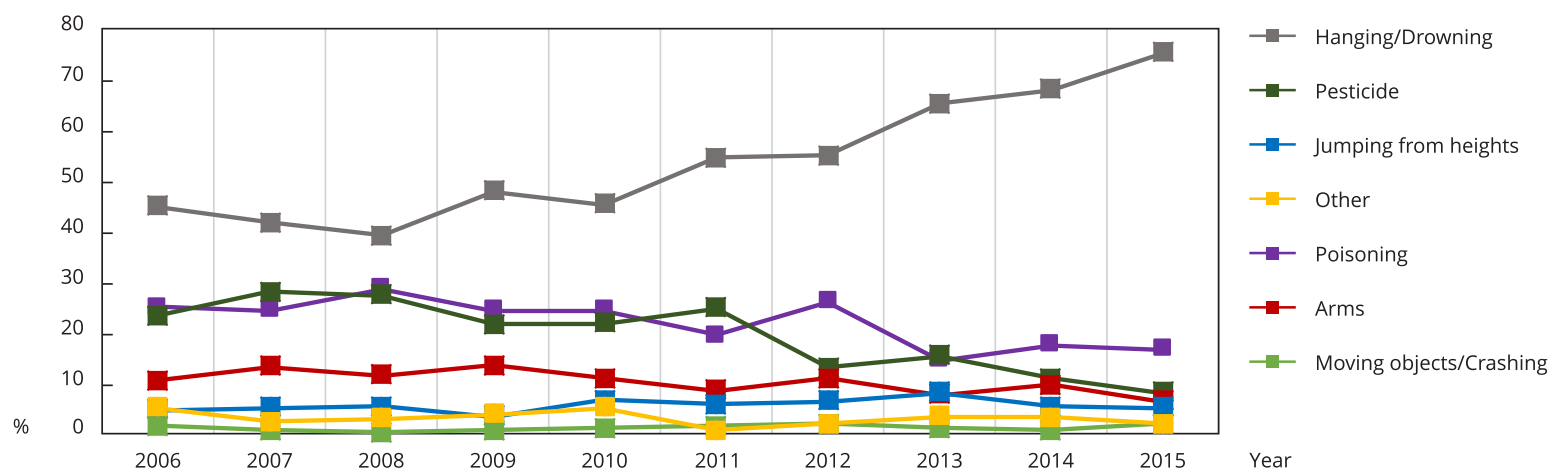

2b) Boys

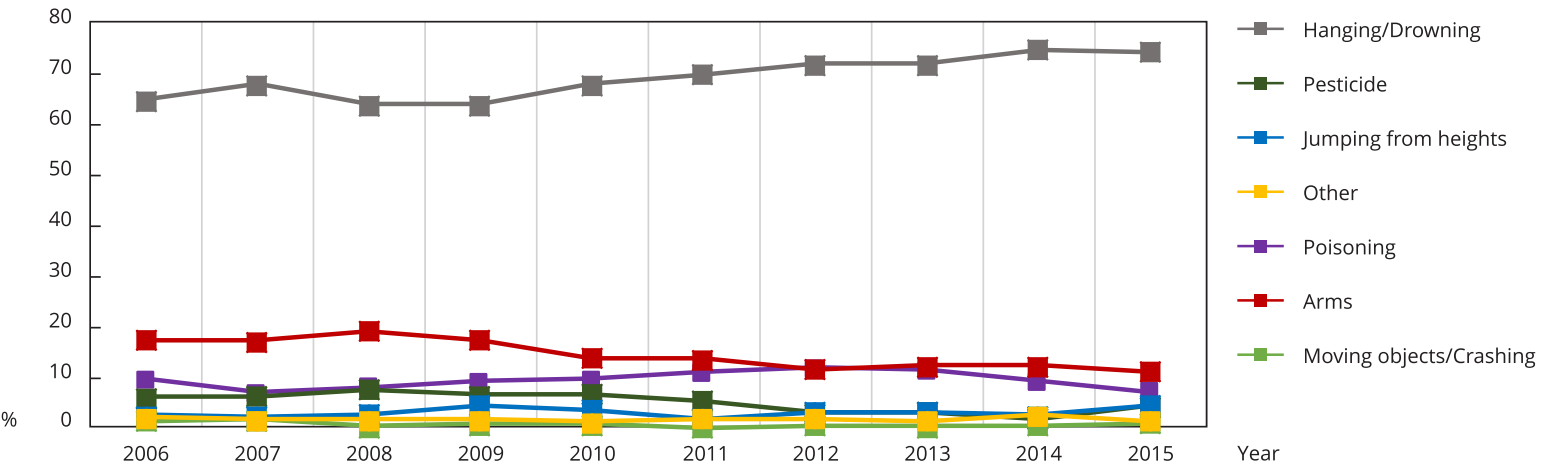


However, recent U.S. legislation restricting access to arms was not associated with a reduction in the number of arms suicides of young men in the U.S. Restricted access to arms, in turn, was associated with a significant reduction in suicide among Canadian men aged 15-34 and young Australians, but with a simultaneous increase in hanging suicides in the latter group 16. In Brazil, the total number of suicides in adolescents by hanging increased from $54.9 \%$ to $70.3 \%$ between $2006-2015$ 1,17,18.

We also found a relative decrease in poisoning over the same period, from $10.7 \%$ to $4.9 \%$. Worldwide, poisoning is a major global health issue, especially in developing countries 8 . Deaths from pesticide ingestion are a major contributor to the global burden of suicide and premature mortality 19 . In Brazil, Law n. 6,670/2016 establishes the National Policy for the Reduction of Agrochemicals, with the aim of implementing actions that contribute to the progressive reduction of the use of agrochemicals in agricultural, livestock, extractive and natural resources management practices 15.

The change may reflect the restriction of access to arms and pesticide in Brazil, leading to an increase in hanging, a highly lethal suicide method. No specific measures seem efficient against this method, probably due the difficulty to impose barriers to avoid it 20. Another explanation could be the increased coverage of medical care in the Emergency Room regarding poisonings and traumas caused by arms 21 .

In our study, patterns of suicide methods in children and adolescents reflect the lethality 22, availability 6 , and cultural acceptability of suicide 23 . Arms and hanging are the most lethal methods, with lethality of $60 \%$ and $47.5 \%$, respectively 6 . Pesticides have also been reported as highly lethal, especially herbicides (42.7\%). The overall death was higher in boys and increased with age 6 . In one study in rural India, suicide rates among women aged 15-24 were higher than those for men of the same age 19. Female suicide rates in India are among the highest in the world 19,24. These rates were believed to be higher in rural India because of the greater availability of pesticides combined with poorer access to emergency medical care 24 .

As the use of methods associated with increased lethality is more likely to result in death, suicide prevention has focused especially on restricting access to suicide methods, which is perhaps where the greatest success has been achieved 25,26,27. Key prevention strategies can be population-based (for instance, mental health promotion, education, awareness by campaigns on mental resilience, responsible media coverage, limited access to suicide methods) as well as targeting high-risk subgroups (e.g., specific school-based programs, educating gatekeepers in different domains, providing crisis hotlines and online help, detecting and coaching families at increased risk) or even focusing on individuals identified as suicidal (e.g., improving mental health treatment, follow-up after suicide attempts and strategies for coping with stress and grief) 28,29 . Studies suggest that low-cost follow-up interventions in which physicians and health professionals contact patients who have attempted suicide (especially patients who do not undergo any treatment) using letters to express concern and support may help to reduce the suicide rate after a psychiatric or general hospital/intensive care discharge 30 .

The main limitation of our study was the possibility of underreporting of suicides by death certificates that indicate the cause of death as undetermined, or other causes, especially in relation to adolescents. There are many reasons for underreporting, such as reluctance of doctors and family members to determine the cause as suicide due to possible cognitive immaturity of adolescents, but also to avoid social stigma and shame for the family of the young person. Data collection can also be influenced by local scarcity of health professionals. Another limitation is the study geographical area, since the precision may vary in different areas due to the country's continental extension.

Preventing adolescent suicide is a global imperative 1,31. Several studies have shown promising initial results regarding the efficacy of follow-up care and suicide prevention 30,32 .

We suggest further research on adolescent suicide rates and methods from 2015, due to the different environmental, social and family influences of modern times. 


\section{Contributors}

D. C. Jaen-Varas contributed to the conception and design, analysis and interpretation of data, and writing of the article. J. J. Mari contributed to the conception and design, analysis and interpretation of data, and critical review of the manuscript due to the important intellectual content. E. Asevedo, R. Borschmann, and E. Diniz contributed to the critical review of the manuscript due to the important intellectual content. C. Ziebold and A. Gadelha contributed to the conception and design, statistical design and interpretation of data, and critical review of the manuscript due to the important intellectual content. All authors approved the final version of the manuscript.

\section{Additional informations}

ORCID: Denisse Claudia Jaen-Varas (0000-00034585-7772); Jair J. Mari (0000-0002-5403-0112); Elson Asevedo (0000-0002-3109-2695); Rohan Borschmann (0000-0002-0365-7775); Elton Diniz (0000-0002-4438-3184); Carolina Ziebold (00000002-7965-6680); Ary Gadelha (0000-0002-09938017).

\section{Acknowledgments}

This study was supported by the Brazilian Graduate Studies Coordinating Board (CAPES; Finance Code 001), and this project is part of the Research and Innovation grant for Prevention of Mental Disorders and Use of Alcohol and other Drugs, funded by the Brazilian Ministry of Health (TED \#176/2017).

\section{References}

1. World Health Organization. Preventing suicide: a global imperative. https://www.who. int/mental_health/suicide-prevention/world_ report_2014/en/ (accessed on 14/Apr/2018).

2. Kolves K, De Leo D. Suicide rates in children aged 10-14 years worldwide: changes in the past two decades. Br J Psychiatry 2014; 205:283-5.

3. Kolves K, De Leo D. Adolescent suicide rates between 1990 and 2009: analysis of age group 15-19 years worldwide. J Adolesc Health 2016; 58:69-77.

4. Asevedo E, Ziebold C, Diniz E, Gadelha A, Mari J. Ten-year evolution of suicide rates and economic indicators in large Brazilian urban centers. Curr Opin Psychiatry 2018; 31:26571.

5. Jaen-Varas D, Mari JJ, Asevedo E, Borschmann R, Diniz E, Ziebold C, et al. The association between adolescent suicide rates and socioeconomic indicators in Brazil: a 10-year retrospective ecological study. Braz J Psychiatry 2019; 41:389-95.

6. Kolves K, de Leo D. Suicide methods in children and adolescents. Eur Child Adolesc Psychiatry 2017; 26:155-64.

7. Souza ER, Minayo MCS, Malaquias JV. Suicide among young people in selected Brazilian State capitals. Cad Saúde Pública 2002; 18:673-83.

8. Lovisi GM, Santos SA, Legay L, Abelha L, Valencia E. Epidemiological analysis of suicide in Brazil from 1980 to 2006. Braz J Psychiatry 2009; 31 Suppl 2:S86-94.

9. Abasse ML, de Oliveira RC, Silva TC, de Souza ER. Epidemiological analysis of morbidity and mortality from suicide among adolescents in Minas Gerais, Brazil. Ciênc Saúde Colet 2009; 14:407-16

10. Conte M, Meneghel SN, Trindade AG, Ceccon RF, Hesler LZ, Cruz CW, et al. Suicide prevention program: case study in a municipality in the south of Brazil. Ciênc Saúde Colet 2012; 17:2017-26.

11. Ministério da Saúde. Portaria no 3.479 , de 18 de dezembro de 2017. Diário Oficial da União 2017; 22 dec.

12. Rede Interagencial de Informação para a Saúde. Indicadores básicos para a saúde no Brasil: conceitos e aplicações. 2a Ed. Brasília: Organização Pan-Americana da Saúde; 2008.

13. World Health Organization. The ICD-10 classification of mental and behavioural disorders. http://www.who.int/classifications/icd/en/ bluebook.pdf (accessed on 30/Apr/2018).

14. Secretaria de Vigilância em Saúde, Ministério da Saúde. Perfil epidemiológico das tentativas e óbitos por suicídio no Brasil e a rede de atenção à saúde. Brasília: Ministério da Saúde; 2017.

15. Câmara dos Deputados. Estatuto do desarmamento. Brasília: Câmara dos Deputados; 2003.

16. Pitman A, Krysinska K, Osborn D, King M. Suicide in young men. Lancet 2012; 379:238392. 
17. Bridge JA, McBee-Strayer SM, Cannon EA, Sheftall AH, Reynolds B, Campo JV, et al. Impaired decision making in adolescent suicide attempters. J Am Acad Child Adolesc Psychiatry 2012; 51:394-403.

18. Kuczynski E. Suicídio na infância e adolescência. Psicol USP 2014; 25:246-52.

19. Gunnell D, Eddleston M. Suicide by intentional ingestion of pesticides: a continuing tragedy in developing countries. Int J Epidemiol 2003; 32:902-9.

20. Ribeiro NM, Castro SS, Scatena LM, Haas VJ. Análise da tendência temporal do suicídio e de sistemas de informações em saúde em relação às tentativas de suicídio. Texto \& Contexto Enferm 2018; 27:e2110016.

21. Botega NJ. Comportamento suicida: epidemiologia. Psicol USP 2014; 25:231-6.

22. Elnour AA, Harrison J. Lethality of suicide methods. Inj Prev 2008; 14:39-45.

23. Goldston DB, Molock SD, Whitbeck LB, Murakami JL, Zayas LH, Hall GCN. Cultural considerations in adolescent suicide prevention and psychosocial treatment. Am Psychol 2008; 63:14-31.

24. Patel V, Ramasundarahettige C, Vijayakumar L, Thakur JS, Gajalakshmi V, Gururaj G, et al. Suicide mortality in India: a nationally representative survey. Lancet 2012; 379:2343-51.
25. Brown GK, Green KL. A review of evidencebased follow-up care for suicide prevention: where do we go from here? Am J Prev Med 2014; 47(3 Suppl 2):S209-15.

26. Zalsman G, Hawton K, Wasserman D, van Heeringen K, Arensman E, Sarchiapone M, et al. Suicide prevention strategies revisited: 10-year systematic review. Lancet Psychiatry 2016; 3:646-59.

27. Hawton K. Suicide prevention: a complex global challenge. Lancet Psychiatry 2014; 1:23.

28. Hepp U, Stulz N, Unger-Koppel J, AjdacicGross V. Methods of suicide used by children and adolescents. Eur Child Adolesc Psychiatry 2012; $21: 67-73$

29. Machado DB, Rasella D, Dos Santos DN. Impact of income inequality and other social determinants on suicide rate in Brazil. PLoS One 2015; 10:e0124934.

30. Bilsen J. Suicide and youth: risk factors. Front Psychiatry 2018; 9:540.

31. The Lancet. Suicide prevention: creating a safer culture. Lancet 2016; 388:1955.

32. Centro de Valorização da Vida. Um setembro mais amarelo. https://www.cvv.org.br/ (accessed on 06/Mar/2019). 


\section{Resumo}

O suicídio entre adolescentes é um importante problema de saúde pública em nível global. O estudo teve como principal objetivo descrever os métodos de suicídio mais usados por adolescentes brasileiros entre 10 e 19 anos de idade, de 2006 a 2015. Foram obtidos dados completos do Departamento de Informática do SUS (DATASUS), codificados em sete categorias de métodos de suicídio. As seguintes análises estatísticas foram realizadas: testes de qui-quadrado $\left(\chi^{2}\right)$ para examinar a associação entre a frequência de cada método de suicídio e o ano do óbito. As razões de chances (OR) e intervalos de 95\% de confiança (IC95\%) compararam as chances relativas entre homens e mulheres para cada método de suicídio. Durante o período analisado, houve 8.026 suicidios entre adolescentes. O enforcamento foi o método de suicídio mais usado em ambos os sexos eram (2015=70,3\%), com um aumento mais agudo em mulheres $(2015=65,82 \%)$. $O$ uso proporcional de armas $(2006=14,2 \%$; $2015=9,1 \%)$ e envenenamento $(2006=13,3 \%$; $2015=9,2 \%$ ) diminuiu ao longo do período. $O$ aumento dos enforcamentos é preocupante, suscitando questões com dificuldades na imposição de barreiras de acesso e a alta letalidade desse método. Nesse contexto, precisa haver uma compreensão mais abrangente dos comportamentos suicidas entre os adolescentes brasileiros para informar as medidas preventivas em geral e, mais especificamente, para elucidar os motivos para o aumento dos suicídios por enforcamento.

Adolescente; Saúde Mental; Suicídio; Estudos de Séries Temporais

\section{Resumen}

El suicidio entre adolescentes se ha convertido en un importante problema de salud pública en todo el mundo. El objetivo de este estudio fue describir los métodos de suicido usados más comúnmente entre adolescentes, con edades comprendidas entre los 10 y 19 años, en Brasil desde 2006 hasta 2015. Los datos completos se obtuvieron del Departamento de Informática del Sistema Único de Salud (DATASUS) y se codificaron en siete categorías de métodos de suicidio. Se realizaron análisis estadisticos: tests chi-cuadrado $\left(\chi^{2}\right)$ para examinar la asociación entre la frecuencia de cada método de suicidio y año. Odds ratios (OR) y los intervalos del 95\% de confianza (IC95\%) compararon las oportunidades relativas de cada método suicidio que se produce entre hombres y mujeres. Se registraron 8.026 suicidios entre adolescentes brasileños durante el período analizado. El método de suicidio más comúnmente usado por ambos sexos fue ahorcamiento $(2015=70,3 \%)$, se observó un aumento más pronunciado en mujeres $(2015=$ 65, 82\%). El uso proporcional de armas (2006 = $14,2 \% ; 2015=9,1 \%) y$ envenenamiento $(2006=$ $13,3 \% ; 2015=9,2 \%)$ descendió durante este periodo. El incremento por ahorcamiento es preocupante, principalmente, en lo que se refiere a las dificultades para imponer barreras de acceso, así como por su alta letalidad. En este contexto, se deberían describir más los comportamientos suicidas entre adolescentes en Brasil para comprenderlos mejor, con el fin de que se tomen medidas de prevención general y, más específicamente, se profundice en las razones del incremento de ahorcamientos.

Adolescente; Salud Mental; Suicidio; Estudios de Series Temporales
Submitted on 09/Jun/2019

Final version resubmitted on 11/Dec/2019

Approved on 07/Feb/2020 